\title{
MANAGEMENT OF INNOVATION FACTORS OF SUSTAINABLE SOCIALLY ORIENTED ECONOMIC DEVELOPMENT: GENERALIZING SCIENTIFIC THEORIES
}

Introduction. The negative tendencies in the development of the national economy and the threatening trends in the demographic situation of Ukraine in recent years determine its further lagging behind the socio-economic level of development of the countries that have chosen the model of an effective socially oriented market economy.

In this regard, the question of exploring ways and opportunities to use innovative factors as a basis for sustainable socially-oriented economic development, as well as finding tools and methods for influencing those areas that may be drivers of further socio-economic development, are of particular importance and need to deepen management methodology innovative factors of sustainable socially oriented economic development.

Problems of sustainable economic development are considered in the works of N. Belikova, R. Gataullin, V. Lyashenko [37], V. Mykytenko, Y. Kharazishvili [37]. The work of such scientists as E. Atkinson [8], D. Bell, M. Weber [11; 32], B. Gubsky, A. Dieton [6], T. Zaslavskaya [11], L. Ehrhardt, D. Kahneman [5], E. Libanova, T. Pickett [7], A. Sen, R. Tyler [9], Y. Kharazishvili [38]. The innovative component of socio-economic development is investigated by G. Androschuk [31], Y. Bazhal [17; 18], N. Bryukhovetska, V. Vyshnevsky, V. Gerasimchuk, P. Druker [23], O. Lapko [16], B. Santo, V. Seminozhenko, R. Solow [22], M. Tugan-Baranovsky [3-4] and J. Schumpeter [19]. The interconnection of social and innovative components of economic development is highlighted in the research of I. Bouleev, M. Zgurovsky, S. Kuznets, P. Nikitenko [1; 15], O. Mekh [28], V. Solovyov, L. Fedulova [2], I. Yashchishina; interdependence of innovative and sustainable development of economy is presented in the works of V. Heitz, B. Malitsky, L. Hannes [30], the combination of ways of providing sustainable and socially oriented development is given in the works of O. Amosh, V. Antonyuk, O. Novikova.

However, the new challenges facing modern economic policy, including those related to the current scientific and technological revolution, require a comprehensive approach to removing obstacles to the simultaneous and balanced promotion of all vectors of economic development, which makes it relevant to summarize scientific theories in context management of innovative factors for sustainable socially oriented economic development.
The purpose of the article is to summarize scientific theories in the format of managing innovative factors for sustainable socially oriented economic development.

Presenting main material. The basic fundamental socio-economic theories of civilizational development of mankind, which outline the format of the new economy in the context of sustainable innovative socio-oriented development, as shown by the study of scientific opinion of authoritative specialists are: 1) noospheric theory, which selects the criterion of priority development. This contributes to the development of postindustrial production forces, the improvement of industrial relations, and the conservation of nature for future generations; 2) neo-Keynesian theory, which provides for the maximum employment of the able-bodied population, as well as active state intervention in the social reproduction of man, society, nature; 3) neo-Marxist theory, which considers the development of science as the main factor of production, which assumes the use of all forms of ownership for sustainable GDP growth (34\% of GDP should be created in the sphere of material production), as well as the state regulation of the optimal structure of stratification of the population. In this case, its main vector of development is "ahead of the accumulation in the intangible sphere, especially in the person, his mind, knowledge, science, education, culture, without which it is impossible to expect GDP growth, efficiency gains in material and intangible production" [1, p. 16-17; 2, p. 134]; 4) conflict theories (M. Weber, V. Muntian - Sociology of economic life), which represent society with a set of specific groups whose ideas and interests diverge at all times; 5) crisis theory and cyclicality (P. Samuelson, M. Tugan-Baranovsky [34]); 6) economic evolutionary theories, in particular innovative theories [11, p. 441]; 7) behavioral theories of economics and theories of inequality: Kahnemann Daniel [5] (satisfaction with life as a combination of psychology and economics), Engus Diton (analysis of consumption, poverty and social security) [6], Thomas Picketti [7] and Anthony Atkinson [8] (exploring the nature of social inequality and its strategy to combat it), Richard Tyler (behavioral economics) [9], separate provisions of the Poor Law Amendment Act of 1834-1948, and the National Law of England "On assistance "(National Assistance Act) 1948 in the centralization of the 
juice assistance to low-income groups [10]; 8) theory of social stratification (T. Zaslavskaya [11] and others); 9) theory of technical and technological structures (M. Tugan-Baranovsky, M. Kondratiev); 10) cybernetic theory of control ( $\mathrm{N}$. Wiener, V. Glushkov), as well as its current modifications is the general theory of optimal control in economics and the theory of automatic control [12]; 10) "The New Theory of Growth", developed in the 1980s by American economist Paul Romero (Endogenous Technological Change) [13] and his followers, suggesting the endogenous nature of technological development; 11) the theory of equivalence of material and spiritual factors in the social development of M. Weber [14, p. 130].

The use of innovative factors as a driving force for sustainable socially oriented economic development has outlined their pivotal role and identified the leading position of innovation theories among the above. So, one of the founders and the developer of the model of innovative socially oriented development of social reproduction of capital in the history of economic thought is the Nobel Prize winner in Economics 1971 Simon Kuznets, the gains of which are "to quantify the economic quantities that are most likely to elucidate the processes of social change" [15, p. 43].

In order to explain the extraordinary nature of the situation that emerges in post-socialist countries, it makes sense to recall the attitude of M. Tugan-Baranovsky [3-4] in the last century in Ukraine, which stood at the origins of an innovative theory that is used by the world. O. Lapko rightly noted that "while in the West the theories of innovative development were studied, analyzed and refined, in Ukraine, as in all countries of the former USSR; theories of innovation were consi- dered anti-class" [16, p. 25]. In industrialized countries, the theory of innovation processes replaced the theory of intensification in the 1980s and became the basis for a new model of economic growth. The above fact determines the expediency of taking into account the factor of power elites (national establishment) in the stratification of the population during the formation of concepts and models of economic development. It is now possible to thoroughly explore innovative theories in the context of the socially-oriented development of the national economy, to identify the root causes of technological change and the place of man in this process.

In addition, innovative theories are studied not only in the field of economics, but also become a beacon for sciences such as sociology, pedagogy, psychology, thus emphasizing its "potential for interdisciplinary". A striking example of what can be the work of Y. Bazhal and Y. Pisotska "The need to study the theory of economic development of J. Schumpeter in Ukrainian institutions of higher education" [17], as well as the first in Ukraine textbook Y. Bazhal "Economic Theory technological change" [18].

The founder of modern economic evolutionary theory is rightly considered J. Schumpeter [19]. The central point of his theory was the exclusive role of "entrepreneur-innovators" as opposed to "just-master", which determines the nature and pace of economic development. Thus, the first reason for the implementation of scientific and technological progress and the first link of the content-logical chain of transformation of the economy on innovative principles is the person, namely the entrepreneur-innovator, who tries to satisfy his own vital interests, which is the main motive of his actions (Fig. 1).

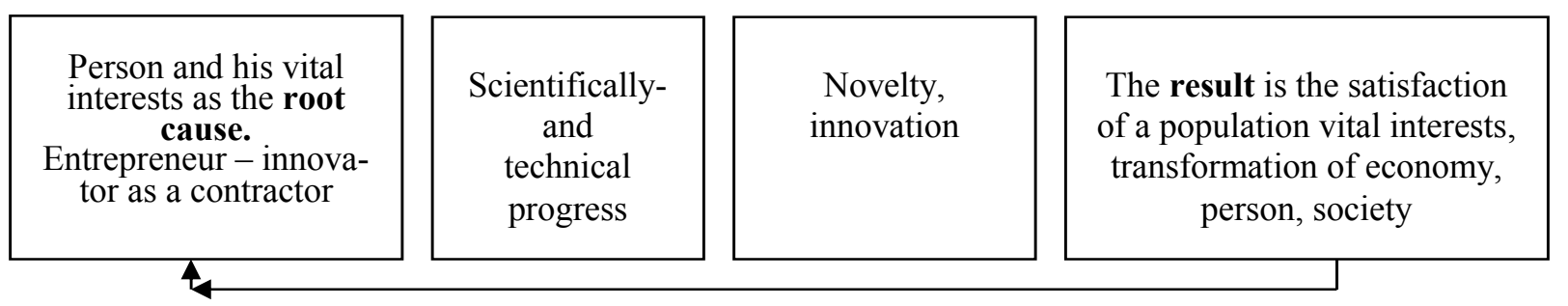

Fig. 1. Person as a factor of transformation of economy on innovative principles

Source: developed by the author.

In this sense of methodological importance is the opinion on the exclusive role of man as a biosocial product. That is, the final result of the social process of production is always the man himself in his social relations, which requires an assessment of state regulation of the development of these processes. P. Nikitenko emphasized the primary importance of human reproduction: "If there is no pre-emptive accumulation in the intangible sphere, especially to the individual, his mind, science, education, culture, then one cannot hope for GDP growth ..." [1, p. 16].
The isolation of the dominant role of the social factor can be found in neoclassical (new classical posthumper) theories [16, p. 32]. Thus, in developing J. Schumpeter's thoughts on basic and secondary innovations, G. Mensh in his work "Basic innovations and innovations of perfection" [20] explains the crisis phenomena by the lack of basic innovations due to the lack of necessary conditions for science and invention. And another representative of the same school M. Kalecki [21, p. 95], formulating their achievements in the work "Theory of Economic Dynamics" states that the interac- 
tion of innovation and economic experience, the main accumulator of which is, again, a person, form a tendency for social development.

In the future, the focus of research has shifted towards highlighting the most significant drivers of GDP growth, that is, dedicated to the phenomenon of technological change as a factor of economic growth. The generalization and confirmation of this idea was the work of the 1987 Nobel Prize winner R. Solow, "Technical Changes and the Function of Cumulative Production" [22], which proved that doubling gross output per one man-hour spent in the United States in 1909-1949 occurred at $12.5 \%$ due to growth in capital labor and $87.5 \%$ - due to technological changes.

B. Malitsky in his work "Neoliberalism and the crisis of innovative economic development, the crisis formula clearly shows that it is innovative progress that predominantly determines the rate of growth of the standard of living of people. That is, it is about scientific and technological progress as an exogenous factor influencing the economic system.

At the same time, models of scientific and technological progress, which foresee the endogenous nature of technological development, are beginning to emerge. This is how the "New Theory of Growth", developed by American economist Paul Romero [13], found its continuation in the writings of V. Golovatyuk.

Peter Drucker in Innovation and Entrepreneurship [23] noted that during the downturns of the industries, economic growth, caused by increased entrepreneurial activity, that is, entrepreneurship and innovation, is the cause of the economic success of US firms due to the effective work of business managers. The main slogan of the proponents of innovative type of development is the willingness to quickly say goodbye to the previous case and constantly find new ones.

At the same time, the Western economic literature of the 1980s focuses on the need for state support for innovative efforts by private firms for several reasons outlined in S. Tisdell's Government Policy Priorities [24], which led to the conclusion that the benefit of intensifying government action in the field of innovation process regulation, without which it is impossible to effectively allocate country resources to obtain a potentially innovative product aimed at satisfying the vital interests of the majority population in the country.

Generalizing the research of scientists of the last decade of the last century in the context of the development of innovative concepts, it is advisable to pay attention to the emergence of socio-psychological theories (H. Barnet, E. Wittie, E. Denison) [16]. This is related to the priority of human relations in the management of innovation. The main place in them are the problems of personal value, the role of the leader's behavior, the level of education in the system of innovation development, as well as the impact of socio-psychological and organizational factors. In the XIX century. M. Tugan-Bara- novsky's submission [3, p. 51] about the economy as a continuous interaction of man (subject) with nature (object) formed his opinion about the growing role of psychological factors in the management of economic systems. Now the power of the state lies in the ability to invent, innovate and unconventional flexible thinking, so the question of the need to use national mental potential, the ability to make fundamentally new decisions, accelerate the solution of tasks, and mastering new ways of thinking can provide the most effective ways out ways out of the crisis [3].

I. Ansoff speaks about the importance of "special" creative type of thinking when solving strategic problems, and P. Drucker defined this way of thinking as innovative [25, p. 406-411].

That is, the driving force of the human factor with the appropriate innovative type of thinking is indispensable in the process of managing innovation. This is the driving force behind completely new knowledge and intelligence of man, which destroys the traditional principles of management of scientific, technical and innovative activities. So, new technologies or revolutionary transformations emerging in a particular industry can lead to the disruption of existing technologies and, as a consequence, change the value proposition of consumers. Clayton Christensen [26] called these technologies disruptive technologies, which, starting a fundamentally new technological cycle of production of goods, destroy the existing basic technology. Old technologies become uncompetitive only because the parameters on which the competition was previously based are no longer relevant. It should be noted that disruptive (breakthrough) technologies are organically linked to strategic and reactive innovations [27], which should be taken into account when supporting and developing innovative systems of economic systems aimed at increasing the satisfaction of vital interests of the majority of the population.

At the same time, the increasing value of the socially oriented innovation vector of development is caused by the emerging contradictions between the opportunities provided by the growing economic dynamics due to the innovative renewal of the capital of industry and the occurrence of relapses in the intensification of the problem of job creation. Addressing the contradictions between growing economic dynamics through innovative capital upgrading and increasing job creation is called for by a socially oriented market economy (CORE). The social orientation of innovative activity implies the focus of the national innovation system on solving the problems of social development, namely: improving the standard and quality of life, energy efficiency, competitiveness, social security, stability, environmental protection. It is about socializing innovation as the ideology of CORE. According to O. Meh, "most scientists recognize the priority of social aspects of scientific, technical and innovative development" [28, p. 22]. 
Under social innovation, most scholars understand the creation of a new social product or service and measures for its implementation, and innovative social activity involves activities aimed at finding, evaluating, developing and applying social innovations.

G. Dobrov [29] raised the issue of the socialization of science, which he defined as "the most rapidly progressing social organism of society".

L. Hannes concludes in favor of socialization of innovations [30, p. 6-12] during the study of the Scandinavian (with its complex social protection) and liberal Anglo-Saxon models, which are on par. Thus, the main reason for the success of European models was the successful reform of the social security system. This, together with the revitalization of policy measures aimed at stimulating research, education and technology transfer, significantly contributed to the reduction of expenditures and stabilization of the state's finances.

Thus, the generalization of innovative theories has made it possible to conclude that the socio-cultural factor, in particular vital human interests, is the root cause of the transformation of the economy on innovative grounds. So, the result of the study of the representatives of the classical school concluded that "the entrepreneur is the bearer of scientific and technological progress". Innovation is the result of scientific and technological progress, and the consequence of innovation is technological change, which, in turn, causes the transformation of the economy, society and man in particular. The established chain of technological change becomes the basis for building the mechanism of transformation of the Ukrainian economy on innovative grounds in the context of the formation of a socially oriented market economy. However, the existence of this type of economy in the country is not yet a sufficient condition for its sustainable development. Professional and real actions of the state and local government bodies are needed to create a favorable environment for innovative development of the country, implementation of economic growth strategies, reengineering of social policy. So, promising areas are innovation, education, competition policy, regulatory and macroeconomic policies, as well as theoretical and empirical models of scientific and technological progress that help illustrate certain situations.

Supporting scientific and technological progress in the country is based on a purely economic calculation of maximizing national income. The obvious and economic feasibility of transferring the external claim received by the state in the form of positive externalities of the innovation process to the private sector, namely to stimulate the dynamics of technological change [18, p. 196]. It is becoming clear not only the possibility but also the expediency of forming a socially oriented economy on an innovative basis: the state, at the expense of obtaining positive externalities, is profitable to satisfy the vital interests of both the individual and society as a whole, because, in the end, it concerns the national security.
That is why Y. Bazhal called technological change a public good [18, p. 191]. Innovation is organically linked to a socially oriented market economy. That is, they are the basis for its development and include positive externalities, namely free resources and consumer benefits to third parties that do not participate in the sale agreement, and therefore are not taken into account in pricing. However, the innovation process is directly related to both positive and negative externalities, that is, the consequences that occur in third parties who are not contractors of market relations in the implementation of a specific agreement between the producer and the consumer of goods.

G. Androschuk, I. Zhilyaev, B. Chizhevsky, M. Shevchenko [31, p. 115] defined the role of the state in the current environment as decisive, especially in ensuring the innovative development of the economy, and also much higher than the role of the market. This finally confirmed the need for state regulation of innovative processes due to their increasing importance for the economy and society as a whole, as well as the limited market mechanisms as a medium for reproduction and diffusion of innovation. Economic cybernetics is called to promote efficiency of state regulation processes.

Cybernetic theory of management, in particular economic cybernetics, the founder of which is traditionally considered by N. Wiener, studies economic systems and issues of automation of management of individual elements of the economy and the economy as a whole. In the case of traditional regulation, the task of sustainability is set. In the visualization of simple economic systems, stability is achieved by selecting the appropriate parameters of the designed system. When the number of impacts and the size of the system are extremely large, self-tuning and self-organization are used to achieve sustainability. However, some of the parameters of the system that determines the nature of its existing connections may change during the functioning of the system. During the removal of the system from the equilibrium it through a special block registers the nature of transients in it [12]. When transient instability is detected, the system changes the value of the parameter relationships until it is stable. Systems of this kind are commonly called "ultra-resistant". V. Glushkov considers modification of cybernetic theory, in particular the theory of optimal control, according to which "in systems of optimal control the main task is to maintain the maximum (or minimum) value of a function of two groups of parameters, called the criterion of optimal control. The parameters of the first group (external conditions) change regardless of the system, the parameters of the second group are regulated, that is, their values can change under the influence of control signals of the system" [12].

Automatic regulation theory is the direction of cybernetic management theory, which studies the auto- 
matic management processes of different physical nature objects (technical cybernetics). However, nowadays, using this theory in adaptive dynamic economic systems can solve the complex problems, associated with increasing the dynamic of challenges and threats.

Analysis of the theory of cycles and crises (P. Samuelson, M. Tugan-Baranovsky) proved a certain frequency of their occurrence and the possibility of prevention. Thus, based on the works of M. Tugan-Baranovsky [3-4], it makes sense to use the deduced pattern and update it in the format of managing innovative factors of sustainable socially oriented development of the economy: "cyclicality of economic dynamics - periodicity of industrial crises - social sphere - satisfaction of vital interest". This creates is the basis for solving the problem of inequality in society.

The theories of inequality by Thomas Pickett [7] and Anthony Atkinson [8] shed light on the main factors behind the stiffening of the population. This is available capital and economic development. Thus, rapid economic growth reduces the role of capital and its concentration in private hands, which reduces social inequality, while slowing growth increases the value of capital and causes injustice to rise.

Anthony Atkinson [8], while revealing the nature of social inequality, devises strategies to combat it, and Richard Tyler [9], combining economics with psychology, has shown that human traits influence decisionmaking and market outcomes. That is, he introduced realistic assumptions about people's actions. In this way, human happiness becomes a goal function, and inequality as an obstacle in its path needs to be minimized through economic growth.

The behavioral theory of economics by R. Thaler sheds light on the combination of economics with psychology, the introduction of more realistic assumptions about people's behavior, driven by the consequences of "limited rationality, social advantages and lack of self-control", as well as the traditional predictions of economists about the rational actions of people and organizations.

Engus Dieton [6] examining the problems of consumption, poverty, and social security with Daniel Kahneman [5] justified the existence of a direct but not linear relationship between material security and happiness in the sense of "life satisfaction" (the happiest are those Americans, who earns about \$ 75,000 a year). In this case 1) consumption theory does not explain the actual relationship, based only on the aggregate (average) indicators of income and consumption; 2) the poverty line is different for all countries (minimum income); 3) home consumption can be estimated as a correlation between income and calorie consumption; 4) the basis for understanding the averaged data currently used in macroeconomics is the analysis of individual data. That is, E. Ditton's methodology is to study consumption at different levels in different countries of the world. Only after that, in his opinion, should we go from partial data to general data. And here the theory of equivalence of material and spiritual factors in the social development of M. Weber comes into force.

However, Rodrick Danny explains the rise in social inequality over the last twenty years by the decline in employment in traditional industrialized countries, with intensive productivity gains as a result of innovative activities and the emergence of a large number of low-productivity jobs, namely social and personal services.

In industrial society, the achieved level of production created the basis for mass consumption, which helped to raise the standard of living of the majority of the population and was reflected in the theory of social stratification, the leading place in which the concept of the middle class.

The foundations of the present understanding of the essence of the middle class as a socio-economic category are laid down in the works of Aristotle and Platon; A. Toynbee, L. Ehrhardt and others. The phenomenon of the middle class in the transitive economy was actively considered by T. Zaslavskaya [11] and others, which was reflected in the writings of the author as a condition and criterion for sustainable development of a socially oriented market economy [34-36].

Now it is worth emphasizing the exceptional role of traditional production in the field of reducing social inequality and the formation of the middle class. The lack of a developed industrial sphere of society causes a sharp stratification of the poor and the rich, as well as provokes social tensions. It becomes apparent that the development of a socially oriented market economy, which is characterized by the presence of the middle class, depends on the efficiency of production.

In this case, the poor state of the production sector or its absence is one of the main reasons for the poor stratification of the population, the decline in the level of social stability in the country.

In unison, Y. Bazhal emphasized the importance of having sufficient productive capacity in the country under the right macroeconomic policy, which will accelerate the correction of the crisis situation, in comparison with the situation when such potential is low or none at all.

Therefore, overcoming the negative phenomena in the national economy is quite possible, provided that innovations in the industry are introduced, which will cause intensive increase of labor productivity and growth of economic dynamics, which will help to increase the level of satisfaction of vital interests of the majority of the population. In doing so, the nuances of behavioral theories of economics should be taken into account. Generalization of scientific theories in the context of managing innovative factors of sustainable development of socially oriented market economy is presented in Fig. 2. 


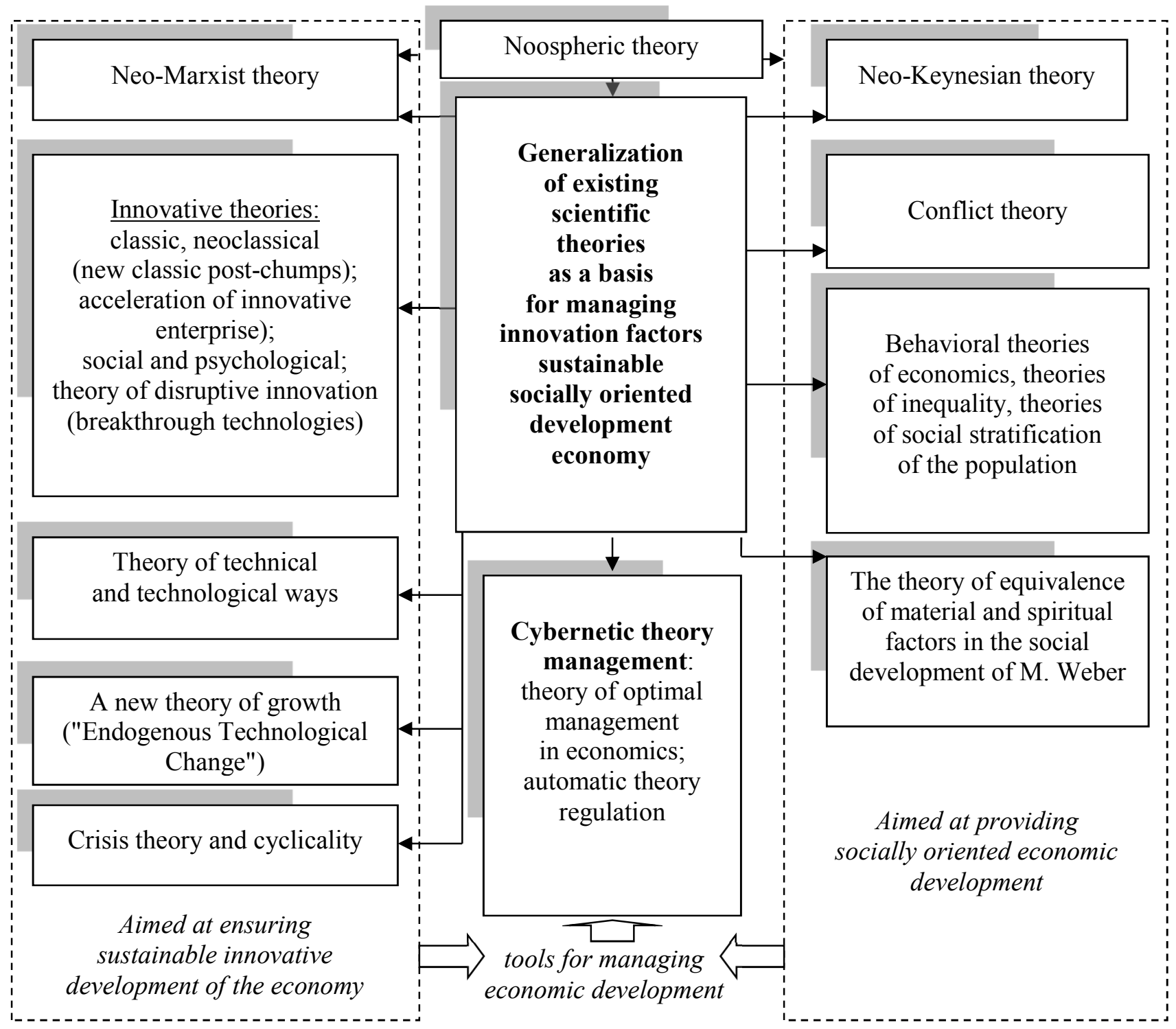

Fig. 2. Generalization of existing scientific theories in the context of managing innovative factors for sustainable socially oriented economic development

Source: generalized, systematized and created by the author.

Conclusion. Based on the generalization of scientific theories, it is revealed that scientific and technological progress (innovative progress) causes an increase in satisfaction with the growing vital interests of the population, manifesting itself as a factor of influence (exogenous and endogenous) on the economic system. Activation of endogenous factors of technological development in current models of scientific and technological progress has determined the crucial role of man as a biosocial product in the growth of GDP of the country and the implementation of scientific and technological progress, namely the entrepreneur-innovator who seeks to satisfy his interests, which are his main motive.

The necessity to consider the qualitative composition of the power elites (national establishment) as a driving force in the formation of concepts and models of economic development is substantiated. Particular attention is paid to the cybernetic theory of control (N. Wiener, V. Glushkov), as well as its current modification, in particular the general theory of optimal control and the theory of automatic control within the economic system.

Emphasis is placed on the expediency of using the theory of automatic regulation in the process of managing the innovative factors of sustainable socially oriented economic development as adaptive dynamic economic systems, which allows solving complex problems related to increasing the dynamics of challenges and threats. 


\section{Literature}

1. Никитенко П. Г. Ноосферная экономика и социальная политика: стратегия инновационного развития. Минск : Белорус. наука, 2006. 479 с. 2. Федулова Л. І. Концепція гуманістично-ноосферного технологічного розвитку в теорії інноватики. Украӥнський соиіум. 2003. № 7. С. 126-138. URL: http://www.ukrsocium.org.ua/Arhiv/Stati/3.2007/126-13 8.pdf (дата звернення: 20.11.2019). 3. Туган-Барановський М. І. Основи політичної економії / автор пер. і вступ. ст. С. М. Злупко. Львів : ЛНУ ім. Івана Франка, 2003. 628 с. 4. Туган-Барановский М. И. Промышленные кризисы. Очерк из социальной истории Англии ; отв. науч. ред. Т. И. Деревянкин. Київ : Наук. думка, 2004. 368 с. 5. Канеман Дэниэль. Думай медленно... решай быстро. Москва: АСТ, 2013. 656 с. 6. Дитон Ангус. Великий побег: Здоровье, богатство и истоки неравенства / пер. с англ. А. Гуськова. Москва: Изд-во Института Гайдара; Фонд «Либеральная Миссия», 2016. 368 с. 7. Пикетги Томас. Капитал в XXI веке. Москва: Ад Маргинем Пресс, 2015. 592 с. 8. Аткинсон Энтони. Неравенство: как с ним быть. Москва: Издательский дом «Дело» РАНХиГС, 2018. 536 с. 9. Тайлер Ричард. Новая поведенческая экономика. Почему люди нарушают правила традиционной экономики и как на этом заработать / пер. с англ. А. Прохорова. Москва: Эксмо, 2017. 352 c. 10 . Mark Blaug. The Myth of the Old Poor Law and the Making of the New. The Journal of Economic History. 1963. Vol. 23. No. 2 (Jun.). P. 151-184. 11. 3aславская Т. И. Структура современного российского общества. Экономические и социальные перемены: мониторинг общественного мнения. 1995. № 6. С. 6-13. 12. Глушков В. М. Кибернетика. Вопросы теории и практики. Москва: Наука, 1986. 488 с. (Наука. Мировоззрение. Жизнь). URL: http://www.etheroneph.com/ cybernetics/376-v-m-glushkov-kibernetika.html (дата звернення: 15.11.2019). 13. Romer P. М. Endogenous Technological Change. The Journal of Political Economy. 1990. Vol. 98. № 5. Part 2. P. 71-72. 14. Вебер М. Хозяйственная этика мировых религий. Библитека Гумер : сайт. Електрон. текст. дані. Москва, [2012-2016]. URL:: http:/www.gumer.info/ bibliotek_Buks/Sociolog/ vebobr/ 02.php (дата звернення: 15.10.2019). 15. Никитенко П. Г. Саймон Смит Кузнец - один из выдающихся экономических креативных мыслителей-экономистов-предтечей инновационных моделей социально-ориентированного экономического роста и ноосферной экономики. Проблемы экономики и управления. 2011. № 2 (39). С. 42-52. 16. Лапко О. Інноваційна діяльність в системі державного регулювання : монографія. Київ : Ін-т економічного прогнозування НАН України, 1999. 254 с. 17. Бажал Ю. М., Пісоцька Ю. А. Необхідність вивчення теорії економічного розвитку Й. Шумпетера в українських університетах. Наукові записки НаУКМА. Педагогічні, психологічні науки та соціальна робота. 2012. Т. 136. С. 14 18. 18. Бажал Ю. М. Економічна теорія технологічних змін. Київ : Заповіт, 1996. 238 с. 19. Шумпетер Й. А. Теорія економічного розвитку: Дослідження прибутків, капіталу, кредиту, відсотка та економічного циклу
/ пер. $з$ англ. В. Старка. Київ : Києво-Могилянська академія, 2011. 242 с. 20. Менш Г. Базисные инновации и инновации совершенствования. Журнал экономики предприятия. 1972. № 42. С. 291-297. 21. Kalecki M. Theory of Economic Dynamics. An Essay on Cyclical and Long-Run Changes in Capitalist Economy. Revue Economique. 1954. Vol. 5. P. 809-811. 22. Solow Robert M. Technical Change and the Aggregate Production Function. The Review of Economics and Statistics. 1957. Vol. 39. № 3. P. 312-320. 23. Drucker Peter F. Innovation and Entrepreneurship. New York: Harper Business, 1985. URL: http://www.roilearning.com/dvm/pubs/reviews/ Innovation_and_Entrepreneurship-1985.pdf (Last accessed: 25.01.2019). 24. Tisdell C. A. Science and Technology Policy Priorities of Government. London; New York: Charman and Hall, 1981. URL: http: //www.worldcat.org/ title/ science-and-technology-policypriorities-of-governments/ oclc/7936814 (Last accessed: 25.01.2019). 25. Ансофф И. Стратегическое управления / сокр. пер с англ.; научн. ред. предисл. Л. И. Евенко. Москва : Экономика, 1989. 519 с. 26. Кристенсен К. М. Диллема инноватора. Как из-за новых технологий погибают сильные компании. Москва : Альпина Бизнес Букс, 2004. 237 с. 27. Бондар О. В. Реактивні інновації як засіб диверсифікації діяльності вітчизняних підприємств в умовах трансформації ринкової економіки та євроінтеграції України. Економіка розвитку. 2004. № 1 (29). С. 78-82. 28. Мех О. А. Інноваційносоціальна модель розвитку фармацевтичної галузі України : дис. ... д-ра екон. наук : спец. 08.00.03 «Економіка i управління національним господарством»; Центр дослідж. наук.-техн. потенціалу та історії науки ім. Г.М. Доброва. Київ, 2009. 418 с. 29. Добров Г. М. Наука о науке. Введение в общее науковедение. Київ : Наукова думка, 1970. 320 с. 30 . Ханнес Л. Інноваційні моделі сталого зростання. Виклики та можливості в умовах глобалізації економіки. Інноваційна політика: Європейський досвід та рекомендаиії для України. [Результати проекту «Вдосконалення стратегій, політик та регулювання інновацій в Україні»]. EuropeAid/ 127694/C/SER/UA; за ред. Гудрон Румпф, Джоржа Строгілопулоса, Ігора Єгорова. Київ : Фенікс, 2011. Т. 1. Розд. 2. С. 7-12. URL: http://kneu.edu.ua/userfiles/ our_partners/gudrun/ 1_UA.pdf (Last accessed: 25.01. 2019). 31. Стратегія інноваційного розвитку України на 2010-2020 роки в умовах глобалізаційних викликів / автор-упоряд. : Г. О. Андрощук, І. Б. Жиляєв, Б. Г. Чижевський, М. М. Шевченко. Київ : Парламентське вид-во, 2009. 632 с. 32. Вебер М. Основные понятия стратификации. Социологические исследования. 1994. № 5. С. 169-183. 33. Сорокин П. А. Социальная и культурная мобильность. Человек. Цивилизация. Общество / общ. ред., сост. и предисл. А. Ю. Согомонов. Москва: Политиздат, 1992. С. 297-424. 34. БондарьПодгурская О. В. Средний класс как необходимое условие устойчивого инновационного социально ориентированного развития экономики. Бізнес Інформ. 2015. № 7. С. 61-66. 35. Бондар-Підгурська О. В. Соціальна стратифікація українського суспільства на шляху до сталого інноваційного розвитку. Наукові 
праці Кіровоградського національного технічного університету. Економічні науки: зб. наук. пр. Кіровоград : КНТУ, 2012. Вип. 21. С. 217-224. 36. БондарПідгурська О. В. Механізм формування середнього класу як основа конкурентоспроможної економіки та сталого інноваційного розвитку України. Економіка та держава. 2012. № 7. С. 22-26. 37. Харазішвілі Ю.М., Ляшенко В.І. Стратегічні сценарії сталого розвитку та інституційні умови досягнення. Економічний вісник Донбасу. 2019. № 3 (57). С. 282-302. 38. Харазішвілі Ю.М. Стратегічні орієнтири рівня життя та рівня освіти як основа існування середнього класу в Україні. Вісник економічної науки Украӥни. 2019. № 1 (36). C. $155-160$

\section{References}

1. Nikitenko P. G. (2006). Noosfernaya ekonomika i sotsial'naya politika: strategiya innovatsionnogo razvitiya [Noosphere Economics and Social Policy: Strategy for Innovative Development]. Minsk : Belorus. nauka [in Russian].

2. Fedulova L. I. (2003). Kontseptsiia humanistychno-noosfernoho tekhnolohichnoho rozvytku $\mathrm{v}$ teorii innovatyky [The concept of humanistic-noospheric technological development in the theory of innovation]. Ukrainskyi sotsium - Ukrainian society, 7, pp. 126-138. Retrieved from http://www.ukr-socium.org.ua/Arhiv/Stati/ 3.2007/126-13 8.pdf [in Ukrainian].

3. Tuhan-Baranovskyi M. I. (2003). Osnovy politychnoi ekonomii [Fundamentals of political economy / author trans. and introduction]. Lviv, LNU im. Ivana Franka [in Ukrainian].

4. Tugan-Baranovskiy M. I. (2004). Promyshlennyye krizisy. Ocherk iz sotsial'noy istorii Anglii [Industrial crises. Essay from the social history of England]. Kyiv, Nauk. dumka [in Russian].

5. Kahneman Daniel. (2013). Think slowly ... decide quickly. Moscow, AST [in Russian].

6. Deaton Angus. (2016). The Great Escape: Health, Wealth, and the Origins of Inequality. Trans. from English. Moscow, Publishing House of the Gaidar Institute; Liberal Mission Foundation [in Russian].

7. Pickets Thomas. (2015). Capital in the 21st century. Moscow, Hell Margin Press [in Russian].

8. Atkinson Anthony. (2018). Inequality: how to deal with it. Moscow, Publishing House Delo RANEPA [in Russian].

9. Tyler Richard. (2017). New behavioral economics. Why do people break the rules of the traditional economy and how to make money from it. Trans. from English. Moscow. Eksmo [in Russian].

10. Mark Blaug. (1963). The Myth of the Old Poor Law and the Making of the New. The Journal of Economic History, Vol. 23, No. 2 (Jun.), pp. 151-184.

11. Zaslavskaya T. I. (1995). Struktura sovremennogo rossiyskogo obshchestva [The structure of modern Russian society]. Ekonomicheskiye i sotsial'nyye peremeny: monitoring obshchestvennogo mneniya - Economic and Social Change: Monitoring Public Opinion, 6, pp. 6 13 [in Russian].
12. Glushkov V. M. (1986). Kibernetika. Voprosy teorii i praktiki [Cybernetics. Questions of theory and practice]. Moscow, Nauka. Retrieved from http://www.ethero neph.com/cybernetics/376-v-m-glushkov-kibernetika.html [in Russian].

13. Romer P. M. (1990). Endogenous Technological Change. The Journal of Political Economy, Vol. 98, № 5, Part 2, pp. 71-72.

14. Weber M. [2012-2016]. Economic Ethics of World Religions. Humer Library.. Moscow. Retrieved from http://www.gumer.info/ bibliotek_Buks/Sociolog/ vebobr/ 02.php [in Russian].

15. Nikitenko P. G. (2011). Saymon Smit Kuznets odin iz vydayushchikhsya ekonomicheskikh kreativnykh mysliteley-ekonomistov-predtechey innovatsionnykh modeley sotsial'no-oriyentirovannogo ekonomicheskogo rosta i noosfernoy ekonomiki [Simon Smith Kuznets is one of the outstanding economic creative thinkers-economists and forerunner of innovative models of socially-oriented economic growth and noosphere economy]. Problemy ekonomiki $i$ upravleniya - Problems of Economics and Management, 2 (39), pp. 42-52 [in Russian].

16. Lapko O. (1999). Innovatsiina diialnist v systemi derzhavnoho rehuliuvannia [Innovative activity in the system of state regulation]. Kyiv, Institute of Economic Forecasting of NAS of Ukraine [in Ukrainian].

17. Bazhal Yu. M., Pisotska Yu. A. (2012). Neobkhidnist vyvchennia teorii ekonomichnoho rozvytku Y. Shumpetera $v$ ukrainskykh universytetakh [The necessity of studying the theory of economic development of J. Schumpeter in Ukrainian universities]. Naukovi zapysky NaUKMA. Pedahohichni, psykholohichni nauky ta sotsialna robota - NaUKMA Scientific Notes. Pedagogical, psychological sciences and social work, Vol. 136, pp. 14-18 [in Ukrainian].

18. Bazhal Yu. M. (1996). Ekonomichna teoriia tekhnolohichnykh zmin [The economic theory of technological change]. Kyiv, Zapovit [in Ukrainian].

19. Shumpeter Y. A. (2011). Teoriia ekonomichnoho rozvytku: Doslidzhennia prybutkiv, kapitalu, kredytu, vidsotka ta ekonomichnoho tsyklu [Economic Development Theory: Research on Profit, Capital, Credit, Interest and the Economic Cycle]. Trans. from English. Kyiv, Kyievo-Mohylianska akademiia [in Ukrainian].

20. Mensh G. (1972). Bazisnyye innovatsii i innovatsii sovershenstvovaniya [Basic innovations and innovations of improvement]. Zhurnal ekonomiki predpriyatiyaJournal of Enterprise Economics, 42, pp. 291-297 [in Russian].

21. Kalecki M. (1954). Theory of Economic Dynamics. An Essay on Cyclical and Long-Run Changes in Capitalist Economy. Revue Economique, Vol. 5, pp. 809811.

22. Solow Robert M. (1957). Technical Change and the Aggregate Production Function. The Review of Economics and Statistics, Vol. 39, № 3, pp. 312-320.

23. Drucker Peter F. (1985). Innovation and Entrepreneurship. New York : Harper Business, Retrieved from http:/www.roilearning.com/dvm/pubs/reviews/ Innovation_and_Entrepreneurship-1985.pdf. 
24. Tisdell C. A. (1981). Science and Technology Policy Priorities of Government. London; New York : Charman and Hall, Retrieved from http://www.worldcat. org/title/science-and-technology-policy-priorities-of-gov ernments/ oclc/7936814.

25. Ansoff I. (1989). Strategic management. Trans from English. Moscow, Ekonomika [in Russian].

26. Christensen K.M. (2004). Dillem innovator. How powerful companies die because of new technologies. Moscow, Alpina Business Books [in Russian].

27. Bondar O. V. (2004). Reaktyvni innovatsii yak zasib dyversyfikatsii diialnosti vitchyznianykh pidpryiemstv v umovakh transformatsii rynkovoi ekonomiky ta yevrointehratsii Ukrainy [Reactive innovations as a means of diversification of activity of domestic enterprises in the conditions of transformation of market economy and European integration of Ukraine]. Ekonomika rozvytku - Economics of development, 1 (29), pp. 78-82 [in Ukrainian].

28. Mekh O. A. (2009). Innovatsiino-sotsialna model rozvytku farmatsevtychnoi haluzi Ukrainy [Innovative and social model of development of pharmaceutical industry of Ukraine]. Doctor's thesis. Kyiv, Tsentr doslidzh. nauk.tekhn. potentsialu ta istorii nauky im. H.M. Dobrova [in Ukrainian].

29. Dobrov G. M. (1970). The science of science. Introduction to general science of science. Kyiv, Naukova Dumka [in Russian].

30. Khannes L. (2011). Innovatsiini modeli staloho zrostannia. Vyklyky ta mozhlyvosti $\mathrm{v}$ umovakh hlobalizatsii ekonomiky [Innovative models of sustainable growth. Challenges and Opportunities in the Globalization Economy]. Innovatsiina polityka: Yevropeiskyi dosvid ta rekomendatsii dlia Ukrainy - Innovation policy: European experience and recommendations for Ukraine [Results of the project "Improving Innovation Strategies, Policies and Regulation in Ukraine"]. EuropeAid/127694/C/SER/UA. Kyiv, Phoenix. Vol. 1, part 2, pp. 7-12. Retrieved from http://kneu.edu.ua/userfiles/our_partners/gudrun/1 UA. pdf [in Ukrainian].

31. Androshchuk H. O., Zhyliaiev I. B., Chyzhevskyi B. H., Shevchenko M. M. (2009). Stratehiia innovatsiinoho rozvytku Ukrainy na 2010-2020 roky v umovakh hlobalizatsiinykh vyklykiv [Strategy of innovative development of Ukraine for 2010-2020 in the conditions of globalization challenges]. Kyiv, Parliamentary Publishing House [in Ukrainian].

32. Veber M. (1994). Osnovnyye ponyatiya stratifikatsii [Basic concepts of stratification]. Sotsiologicheskiye issledovaniya - Sociological studies, 5, pp. 169-183 [in Russian].

33. Sorokin P.A. (1992). Social and cultural mobility. Man. Civilization. Society. Moscow, Politizdat (pp. $297-$ 424) [in Russian].

34. Bondar'-Podgurskaya O. V. (2015). Sredniy klass kak neobkhodimoye usloviye ustoychivogo innovatsionnogo sotsial'no oriyentirovannogo razvitiya ekonomiki [The middle class as a necessary condition for sustainable innovative socially-oriented economic development]. Bíznes Ínform - Business Inform, 7, pp. 61-66 [in Russian].
35. Bondar-Pidhurska O. V. (2012). Sotsialna stratyfikatsiia ukrainskoho suspilstva na shliakhu do staloho innovatsiinoho rozvytku [Social stratification of Ukrainian society on the way to sustainable innovative development]. Naukovi pratsi Kirovohradskoho natsionalnoho tekhnichnoho universytetu. Ekonomichni nauky. Scientific papers of Kirovograd National Technical University. Economic Sciences, Issue 21, pp. 217-224. Kirovohrad, KNTU [in Ukrainian].

36. Bondar-Pidhurska O. V. (2012). Mekhanizm formuvannia serednoho klasu yak osnova konkurentospromozhnoi ekonomiky ta staloho innovatsiinoho rozvytku Ukrainy [The mechanism of middle class formation as a basis for competitive economy and sustainable innovative development of Ukraine]. Ekonomika ta derzhava - Economy and the state, 7, pp. 22-26 [in Ukrainian].

37. Kharazishvili Yu.M., Liashenko V.I. (2019). Stratehichni stsenarii staloho rozvytku ta instytutsiini umovy dosiahnennia [Strategic sustainable development scenarios and institutional conditions for achievement]. Ekonomichnyi visnyk Donbasu - Economic Herald of the Donbas, 3 (57), pp. 282-302. doi: 10.12958/1817-37722019-3(57)-282-302 [in Ukrainian].

38. Kharazishvili Yu.M. (2019). Stratehichni oriientyry rivnia zhyttia ta rivnia osvity yak osnova isnuvannia serednoho klasu v Ukraini [Strategic Benchmarks for Living Standards and Education as a Basis for the Existence of a Middle Class in Ukraine]. Visnyk ekonomichnoi nauky Ukrainy - Bulletin of Economic Science of Ukraine, 1 (36), pp. 155-160 [in Ukrainian].

Бондар-Підгурська О. В. Управління інноваційними факторами сталого соціально орієнтованого розвитку економіки: узагальнення наукових теорій

Узагальнено наукові теорії у контексті управління інноваційними факторами сталого соціально орієнтованого розвитку економіки. Проаналізовано та синтезовано концепції наукових теорій спрямованих на забезпечення сталого інноваційного соціально орієнтованого розвитку економіки (ноосферна, неокейнсіанська, неомарксистська, конфліктності, теорії криз і циклічності, економічні еволюційні теорії, зокрема інноваційні; поведінкові економіки та нерівності, соціальної стратифікації; техніко-технологічних укладів; рівнозначності матеріальних і духовних чинників у суспільному розвитку, «Нова теорія зростання»), а також інструменти управління ним, які дозволяють розв'язувати складні проблеми, пов'язані із підвищенням динамізму викликів і загроз (кібернетична теорія управління: теорія оптимального управління в економіці та теорія автоматичного регулювання). У результаті обгрунтовано науково-технічний прогрес (інноваційний розвиток) як фактор задоволення життєво важливих інтересів населення, а якісний склад владних еліт (національного істеблішменту) як рушійні сили економічного розвитку у частині прийняття управлінських рішень, розробки концепцій, стратегій і його моделей. 
Виявлено причини та чинники нерівності, усунення та вчасне управління якими допоможе оптимізувати структуру стратифікації населення.

Наголошено на доцільності упередження та подолання негативних явищ за рахунок вчасного впровадження нововведень у промисловість, що спричинить інтенсивне підвищення продуктивності праці та зростання економічної динаміки, яка, в свою чергу, забезпечить задоволення життєво важливих інтересів більшості населення країни.

Ключові слова: сталий розвиток, інноваційні фактори, соціально орієнтована ринкова економіка, життєво важливі інтереси, нерівність, стратифікація населення.

Bondar-Pidhurska O. Management of Innovation Factors of Sustainable Socially Oriented Economic Development: Generalizing Scientific Theories

Scientific theories are generalized in the context of managing innovative factors of sustainable socially oriented economic development. Concepts of scientific theories aimed at ensuring sustainable innovative socially-oriented economic development (noospheric, neo-Keynesian, neo-Marxist, conflict, crisis and cyclical theories, economic evolutionary theories, including innovative ones; economics of behavior and inequality, social stratification; technical and technological structures; equivalence of material and spiritual factors of social development, «New theory of growth»), as well as tools for managing them to solve complex problems related to increasing the dynamics of challenges and threats (cybernetic control theory: theory of optimal control in economics and theory of automatic control)), have been analyzed and synthesized.

Scientific and technological progress (innovative development) as a factor of satisfaction of vital interests of the population and qualitative composition of the power elites (national establishment) as a driving force of economic development from the point of view of decisionmaking, concept development, strategy and its models were substantiated as a result.

The importance of preventing and overcoming negative phenomena by timely introduction of innovations into industry is emphasized, which will lead to intensive increase of labor productivity and growth of economic dynamics, which, in turn, will ensure the satisfaction of the majority population country vital interests.

The reasons and factors of inequality, elimination and timely management which will help to optimize the structure of country population stratification are revealed.
Keywords: sustainable development, innovative factors, socially oriented market economy, vital interests, inequality, stratification of population.

Бондар-Подгурская О. В. Управление инновационными факторами устойчивого социально ориентированного развития экономики: обобщение научных теорий

Обобщены научные теории в контексте управления инновационными факторами устойчивого социально ориентированного развития экономики. Проанализированы и синтезированы концепции научных теорий направленных на обеспечение устойчивого инновационного социально ориентированного развития экономики (ноосферная, неокейнсианская, неомарксистская, конфликтности, теории кризисов и цикличности, экономические эволюционные теории, в частности инновационные; поведенческой экономики и неравенства, социальной стратификации; технико-технологических укладов; равнозначности материальных и духовных факторов в общественном развитии, «Новая теория роста»), а также инструменты управления им, которые позволяют решать сложные проблемы, связанные с повышением динамизма вызовов и угроз (кибернетическая теория управления: теория оптимального управления в экономике и теория автоматического регулирования). В результате обоснованы научно-технический прогресс (инновационное развитие) как фактор удовлетворения жизненно важных интересов населения, а качественный состав властных элит (национального истеблишмента) как движущие силы экономического развития в части принятия управленческих решений, разработки концепций, стратегий и его моделей.

Выявлены причины и факторы неравенства, устранение и своевременное управление которыми поможет оптимизировать структуру стратификации населения.

Отмечена целесообразность предупреждения и ликвидации негативных явлений за счет своевременной реализации нововведений в промышленность, что повлечет интенсивное повышение производительности труда и роста экономической динамики, которая, в свою очередь, обеспечит удовлетворение жизненно важных интересов большинства населения страны.

Ключевые слова: устойчивое развитие, инновационные факторы, социально ориентированная рыночная экономика, жизненно важные интересы, неравенство, стратификация населения.

Received by the editors: 06.12.2019 and final form 19.12.2019 